\title{
Isolated abducens nerve palsy secondary to lung metastases
}

Hayatulrizal Muhd ${ }^{1}$, Hayati Abdul Aziz¹, Francesca Martina Vendargon ${ }^{1}$, Jasmi Ramlan², Yeoh Aik Guan ${ }^{3}$

${ }^{1}$ Department of Ophthalmology, Hospital Sultanah Aminah, Johor Bahru, Johor, Malaysia; 'Department of Pathology, Hospital Sultanah Aminah, Johor Bahru, Johor, Malaysia; ${ }^{3}$ Department of Radiology, Hospital Sultanah Aminah, Johor Bahru, Johor, Malaysia

\section{Abstract}

We present a rare case of metastatic lung adenocarcinoma which presented as isolated abducens nerve palsy. A 65-year-old healthy woman presented with horizontal diplopia of three months duration. Her best-corrected visual acuity was $6 / 18$ bilaterally with no relative afferent pupillary defect. Ocular examination showed limited abduction of the right eye. Anterior and posterior segment examination was normal in both eyes. However, she had a non-tender enlarged lymph node at the left supraclavicular area. The systemic review was unremarkable. C-reactive protein, erythrocyte sedimentation rate, and serum alpha-fetoprotein were markedly raised. A chest X-ray revealed right upper lobe opacity with a satellite nodule. Computed tomography of the brain, orbit, thorax, abdomen, and pelvis exhibited a heterogeneously enhancing mass at the right upper lobe of the lung with metastasis to the left frontal, right occipital, and left parietal lobe as well as multiple bone metastases. With histopathology confirmation of lung tissue biopsy, she was diagnosed as isolated right abducens nerve palsy secondary to metastatic lung adenocarcinoma. She was referred to the respiratory, neuromedical, and oncology units for further management. In conclusion, although this appeared to be an isolated case, lung metastasis should be considered in the differential diagnosis of isolated abducens nerve palsy. Hence, lung examination should be performed when encountering such cases.

Keywords: abducens nerve palsy, adenocarcinoma, lung adenocarcinoma, neuro-ophthalmology, sixth nerve palsy

Correspondence: Dr. Muhammad Hayatulrizal, Ophthalmology Department, Hospital Sultanah Aminah Johor Bahru, Johor, Malaysia.

E-mail: hayatulrizal@yahoo.com 


\section{Palsi saraf abdusen akibat metastasis dari paru-paru}

\section{Abstrak}

Kami membentangkan satu kes yang jarang berlaku tentang metastasis adenokarsinoma paru-paru yang bermula dengan gejala terpencil palsi saraf abdusen. Seorang wanita yang sihat berusia 65 tahun mengadu mengalami diplopia selama tiga bulan. Ketajaman penglihatannya yang terbaik adalah $6 / 18$ pada kedua-dua belah mata tanpa kecacatan relatif aferen anak mata. Peperiksaan okular menunjukkan pergerakan mata yang terhad. Pemeriksaan segmen anterior dan posterior adalah normal di kedua-dua mata. Walau bagaimanapun, dia mempunyai nod limfa yang tidak menyakitkan di bahagian supraklavikular kiri. Pemeriksaan klinikal pada bahagian sistemik adalah normal. Terdapat peningkatan ketara protein C-reaktif, kadar pemendapan eritrosit, dan alpha-fetoprotein serum. Ujian X-ray dada menunjukkan opasiti lobus kanan atas dengan nodul satelit. Tomografi komputasi otak, orbit, toraks, abdomen, dan pelvis mempamerkan kehadiran ketumbuhan yang bersifat heterogenus pada lobus kanan paru-paru dengan metastasis ke frontal kiri, osipital kanan, dan lobus parietal kiri bahagian otak serta beberapa kesan metastasis pada tulang. Dengan pengesahan histopatologi biopsi tisu paru-paru, dia akhirnya didiagnos sebagai palsi saraf abducens kanan terpencil akibat dari kesan metastasis adenorkarsinoma paru -paru. Dia dirujuk ke unit respiratori, neurologi perubatan, dan onkologi untuk rawatan lanjut. Sebagai kesimpulan, walaupun kes ini kelihatan sebagai kes terpencil, metastasis paru-paru perlu dipertimbangkan sebagai salah satu penyebab palsi saraf abduscen terpencil Oleh itu, pemeriksaan paru-paru perlu dilakukan apabila menghadapi kes-kes seperti ini.

Kata kunci: adenokarsinoma, adenokarsinoma paru-paru, neuro-optalmologi, palsi saraf abdusen, palsi saraf keenam

\section{Introduction}

Most isolated abducens nerve palsies are ischemic in nature. ${ }^{1}$ However, there are other life-threatening causes of abducens nerve palsy. Some require prompt diagnostic and therapeutic management, as delayed treatment may lead to increased morbidity and/or mortality. In this report, we present a rare case of metastatic lung adenocarcinoma that presented as isolated abducens nerve palsy. 

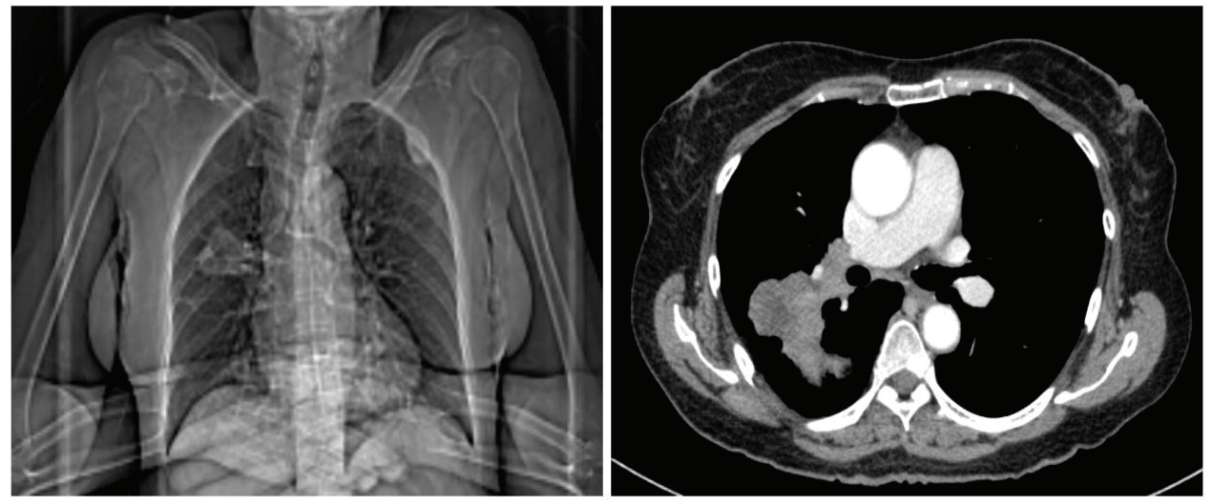

Fig. 1. Coronal plane of TAP CT (left) showing heterogeneously enhancing mass at the posterior segment of the right upper lobe of the lung. Axial image of thorax CT (right) showing enhancing mass at the posterior segment of the right upper lobe.

\section{Case report}

A 65-year-old woman and passive smoker for 30 years presented with a three-month history of binocular horizontal diplopia and significant weight loss. The diplopia was persistent throughout the day and improved slightly on tilting her head to the right. However, there was no associated pain, red eye, headache, vomiting, seizures, or body weakness. She denied any concurrent fever, nasal, or gastro-urinary symptoms. There was no high-risk behaviour. Her best-corrected visual acuity was $6 / 18$ bilaterally with no relative afferent pupillary defect. On examination, there was limited abduction of the right eye associated with a right-sided head tilt. Anterior segment was normal in both eyes. Dilated fundus examination of both eyes revealed no optic disc swelling. Examination of other cranial nerves was normal. A non-tender enlarged lymph node was detected in the left supraclavicular area. Systemic review and examination of the chest, abdomen, and breasts were normal.

Blood investigations revealed markedly raised C-reactive protein $(144 \mathrm{mg} / \mathrm{dl})$, erythrocyte sedimentation rate $(60 \mathrm{~mm} / \mathrm{hr})$, and serum alpha-fetoprotein. A chest X-ray revealed a right upper lobe opacity with a satellite nodule. Computed tomography (CT) of the brain, orbit, thorax, abdomen, and pelvis (TAP) exhibited a heterogeneously enhancing mass at the posterior segment of right lung upper lobe (Fig. 1) with metastases to the left frontal, right occipital, and left parietal lobes (Fig. 2, left). There were sclerotic lesions at the body, lamina, and pedicles of T4-T5 as well as right iliac bone, proximal left femoral head, and right tenth rib in keeping with bony metastases.

The patient underwent CT-guided, fine-needle aspiration biopsy of the lung. Histopathology examination (HPE) of lung tissue biopsy revealed adenocarcinoma 

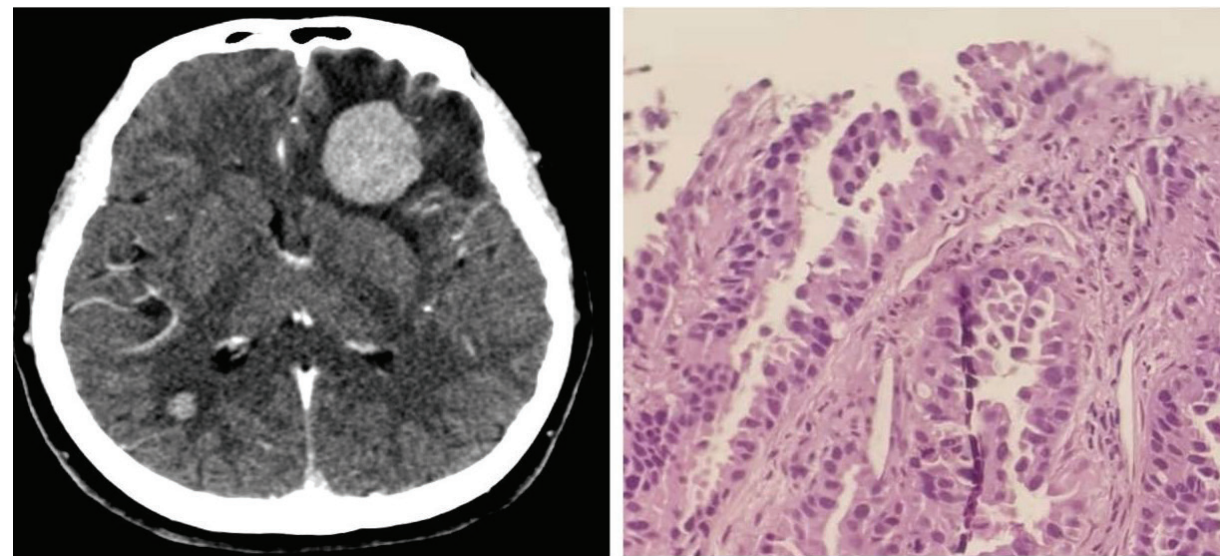

Fig. 2. Axial image of brain CT (left) showing metastases to left frontal and right occipital. HPE of lung tissue (right) showing tumour forming acinar pattern, no nuclear moulding, nesting, or rosette formation.

with features of malignant cells forming an acinar pattern with no nuclear moulding, nesting, or rosette formation (Fig. 2, right). The tumour cells were positive towards thyroid transcription factor-1 (TTF-1), napsin A, but were negative for CD56, synaptophysin and chromogranin immunostains.

A diagnosis of isolated right abducens nerve palsy secondary to metastatic lung adenocarcinoma was made. The patient was referred to the oncology team and started on 20 Gy whole-brain radiotherapy given in 5 fractions. Subsequently, she received four cycles of palliative double-agent chemotherapy including platinum-based cisplatin and gemcitabine.

Her general medical condition deteriorated with development of a new pathological fracture of the right humerus and femur despite post-chemotherapy imaging showing the radiological and objective clinical response. She was then managed by palliative and supportive care to provide comfort and quality of life.

\section{Discussion}

Sixth nerve palsies occurring in the middle-aged group arise from a variety of causes, with the two most common being vascular (18-37\%) and idiopathic (21-30\%). ${ }^{1}$ The abducens nerve is prone to trauma and metastatic lesion due to its long intracranial course. Metastasis from lung, breast, liver, colon, and prostate have been previously reported in the literature to cause isolated and multiple cranial nerve palsies. ${ }^{2}$

The prevalence of brain metastasis in the presence of systemic malignancy ranges from $8-15 \% .^{3-5}$ In Malaysia, lung cancer accounts for $10.2 \%$ of brain metastases and $16.2 \%$ of patients with lung cancer will develop brain metastasis within five years 
of diagnosis ${ }^{5,6}$ However, the prevalence of a brainstem metastasis is relatively rare, accounting for approximately $5-7 \%{ }^{3,7,8}$ Patients with brainstem lesions involving the abducens nerve classically present with binocular horizontal diplopia, as observed in this patient.

Despite vascular disorders being the commonest cause of abducens nerve palsy in middle-aged individuals, any lesion at the level of cerebellopontine angle, particularly that involving the abducens nerve, can present with abducens nerve palsy. As observed in this patient, malignancy was the main differential diagnosis in the setting of her being a chronic passive smoker and in the presence of constitutional symptoms.

Other tumours which can affect the cerebellopontine area include nasopharyngeal carcinoma and acoustic neuroma. ${ }^{9}$ Classically, the cranial nerves in this area (facial and vestibular nerves) may also be affected, producing added signs and symptoms of decreased hearing and /or facial paralysis. In this case, the patient did not show any signs of other cranial nerve involvement.

Due to clinical suspicion of malignancy, contrast-enhanced computed tomography (CECT) was performed urgently, revealing multiple lesions involving the lung, brain, and bones. Metastases into the brainstem may be too small to be detected by CT scan, and magnetic resonance imaging (MRI) of the brain may be necessary. ${ }^{10}$ However, there was no MRI evidence to suggest a metastatic lesion. Gaze palsy resulting from the metastatic lesion in the facial colliculus of lower pons detected on MRI has been reported by Han et al. ${ }^{11} \mathrm{~A}$ case by Reyes et al. also reported a metastasized brainstem lesion causing abducens nerve palsy as evidenced on MRI imaging. ${ }^{12}$

Based on the above literature review, there is high a likelihood that the metastasis causing isolated nerve palsy may be located at the abducens nucleus at the pontine region.

As the histopathological examination of the lung tissue biopsy yielded a result compatible with lung adenocarcinoma metastasized to the brain and bones with immunohistochemistry analysis suggesting the lung as an organ of origin, radiation therapy followed by palliative chemotherapy was recommended.

The prognosis of lung carcinoma in the presence of distant metastases is generally poor. ${ }^{13}$ Despite that, palliative treatment including radiotherapy, chemotherapy, and hormonal treatment was started. Radiotherapy is still the mainstay treatment for orbital and brain metastases, with response rates up to $79 \%$ and $80 \%$ which may restore vision may induce cataract formation and radiation retinopathy. ${ }^{14} \mathrm{~A}$ study by Ramesh et al. found a response rate in $88 \%$ of patients who completed 30 Gy dose in 10 fractions over one month. ${ }^{15}$

Chemotherapy has high response rates up to $35 \%$ with a survival rate of $15 \%$ in 2 years. ${ }^{13}$ Double-agent regimens such as the platinum- gemcitabine combination used in our case has been proven to be superior to single-agent regimens. ${ }^{16}$ Hormonal therapy, such as gefitinib, can be given in the presence of EGFR tyrosine 
kinase mutation and disease progression. It has been proven to exhibit objective clinical response and shows significant anti-tumour activity as a single agent when started in relapsed non-small-cell lung carcinoma patient. ${ }^{13}$

The most challenging aspect to diagnose this case was its rarity and limited knowledge about it. We believe our case increases the knowledge of metastatic patterns of lung cancer and assists ophthalmologists in identifying and managing patients presenting with isolated abducens nerve palsy.

\section{Conclusion}

This case highlights several important points. The aetiology of abducens nerve palsy is diverse, ranging from benign to life-threatening. Metastatic lung carcinoma, although rare, should be considered when encountering isolated abducens nerve palsy with a suggestive history of passive smoking and constitutional symptoms. The diagnosis was made on a high index of suspicion of the varied symptoms. Hence, a thorough lung examination with radiological and pathological analysis is required to establish the diagnosis, which can be life-saving.

\section{References}

1. Rush JA, Younge BR, Paralysis of cranial nerves III, IV and VI. Cause and prognosis in 1,000 cases. Arch Ophthalmol. 1981;99:76-79.

2. Chandrashekhar MN, Kishore K, Lakshmaiah V, Nagesha CK, Kumar BN. Clivus metastasis presenting as isolated abducens nerve palsy- A case report. J Evol Med Dent Sci. 2013;43:8383-8385.

3. Kased N, Huang K, Nakamura JL, et al. Gamma Knife radiosurgery for brainste metastases: the UCSF experience. J Neurooncol. 2008;86:195-205.

4. Posner JB, Chernik NL. Intracranial metastasis from systemic cancer. Adv Neurol. 1978;19:579-592

5. Schouten LJ, Rutten J, Huveneers HA, Twijnstra A. Incidence of brain metastases in a cohort of patients with carcinoma of breast, colon, kidney, and lung and melanoma. Cancer. 2002;94:26982705.

6. Azizah Ab M, Nor Saleha IT, Noor Hashimah A, Asmah ZA, Mastulu W. Malaysian National Cancer Registry Report 2007-2011. National Cancer Registry; 2015.

7. Barnholtz-Sloan JS, Sloan AE, Davis FG, et al. Incidence proportions of brain metastases in patients diagnosed (1973 to 2001) in the Metropolitan Detroit Cancer Surveillance System. J Clin Oncol. 2004;22:2865-2872.

8. Chason JL, Walker FB, Landers JW. Metastatic carcinoma in central nervous systema nd dorsal root ganglia. A prospective autopsy study. Cancer. 1963;16:781-787.

9. Park KA, Oh SY. Nasopharyngeal carcinoma presenting with rapidly progressive severe binocular optic neuropathy and periocular pain in a young man. J Neuroophthalmol. 2010;30:150-152. 
10. Pusateri TJ, Sedwick LA, Margo CE. Isolated inferior rectus muscle palsy from a solitary metastasis to the oculomotor nucleus. Arch Ophthalmol. 1987;105:675-677.

11. Han SB, Kim JH, Hwang JM. Presumed metastasis of breast cancer to the abducens nucleus presenting as gaze palsy. Korean J Ophthalmol. 2010;24:186-188.

12. Reyes KB, Lee HY, Ng I, Goh KY. Abducens (sixth) nerve palsy presenting as a rare case of isolated brainstem metastasis from a primary breast carcinoma. Singapore Med J. 2011;52:e220-222.

13. Claire Saadeh, Pharm. D., BCOP. Pharmacotherapy self-assessment program, $6^{\text {th }}$ edition. PSAP. 57-71.

14. Liangchao Sun, Yali Qi, Xindong Sun, Jinming Yu, Xue Meng. Orbital Metastases as the initial presentation of lung adenocarcinoma: A case report. Onco Targets Ther. 2016;9:2643-2648.

15. Ramesh S Bilimagga, S Nirmala, Karthik S, et al. Role of palliative radiotherapy in brain metastasis. Indian J Palliat Care. 2009;15(1):71-75.

16. Socinski MA, Evans T, Gettinger S, et al. Treatment of stage IV non-small cell lung cancer: diagnosis and management of lung cancer, 3rd ed: American College of Chest Physicians evidence-based clinical practice guidelines. Chest. 2013;143(5Suppl):e341S-e368S. 